\title{
DIE TEOLOGIESE STUDENTEVERENIGING (T.S.V.)
}

Met die oprigting van die Teologiese Skool te Burgersdorp, was die studentetal maar gering. Stadigaan het die getal gegroei saam met die Skool. So het daar nuwe behoeftes ontstaan, nie alleen t.o.v. die Skool self nie-maar ook die studentegemeenskap het dit nodig gevind om hom as sodanig te organiseer. Die studentelewe het dan ook 'n vaste vorm aangeneem met die stigting van die vereniging „Korps Veritas Vincet” (Junie 1894). In hierdie vereniging het die teologiese studente van byna 'n halwe eeu gelede hulle probleme bespreek en ook hulle samelewing georden. Oor die geskiedenis van Korps wei ons nie uit nie-die leser vind elders in die uitgawe 'n uitvoerige beskrywing daarvan. Ons kan alleen meld dat vooraanstaande manne in ons Kerk en ook in die volkslewe hulle eerste „probleme" op eg studentikose wyse in die geledere van K.V.V. probeer oplos het. Dink maar aan ds. J. A. van Rony (stigter), ds. N. H. v.d. Walt, prof. dr. J. D. du Toit en van die ,jongeres” ds. J. V. Coetzee, prof. L. J. du Plessis e.a.

Lank het Korps V.V. die vereniging gebly wat die studentelewe, ook van die veel jonger P.U.K., beheers het. Maar met die selfstandigwording van die P.U.K. het sake enigsins moeilik begin word. Die Teologiese Skool het wel noú verbonde gebly aan die inrigting, maar tog het met die uitbreiding van laasgenoemde weer nuwe behoeftes ontstaan. Meer en meer het studente wat in ander rigtings as die teologie belang gestel het, 
hulle gewend tot die P.U.K. Gevolg was die ontwikkeling van 'n eie studentelewe. Die Korps het by die P.U.K. gebly as Calvinistiese vereniging en was so nie meer instaat om in al die behoeftes van die Teologiese studente te voorsien nie. Eindelik het dan die "Teologiese Klub" totstand gekom as die vereniging vir Teoloë en Aspirante. Later is die naam verander na die tans bestaande.

T.S.V. se bestaan is daardeur te regverdig dat dit die enigste vẹreniging is waarin die teologiese studente hulself kan saamsnoer as teoloë. Veral in die later jare tree die betekenis en noodsaaklikheid van so 'n vereniging duideliker op die voorgrond. Vanweë die noue samcwerking tussen die P.U.K.-studente en die teologiese studente, bestaan die gevaar dat die groter, hoewel jonger, P.U.K.-studentelewe, eersgenoemde heeltemal kan absorbeer. Deur T.S.V. word egter nou 'n bewustheid van 'n eie teologiese studentegemeenskap gevorm. En dit het veral groot betekenis vir die aankomende teoloë. Dit bring hulle in kontak met die reeds gevorderde studente. Soos reeds gesê bied die vereniging ook die geleentheid om sake eie aan die Skool alleen te bespreek ens.

Verder sal opgemerk word in die Konstitusie (Pg. 35 TeologieseSkoolboekie) dat die vereniging trag om ook vormend in te werk op die studente. Allerlei teologiese kwessies word bestudeer en kennis geneem van die heersende strominge in die wêreld van die denke. So word ook in T.S.V. getrag om die lede vertroud te maak met die kerklike lewe en ook die probleme wat hulle kan voordoen in die latere lewe.. Waardevol in dié verband is die jaarlikse optrede van een van die Professore en die Pastor loci.

Die afgelope drie jaar is daar ook 'n nouere samewerking tussen T.S.V. en die verenigings aan die Kweekskole van die N.G.-Kerk te Stellenbosch, Pretoria en Wellington, wat veral openbaar word in die verskyning van die „Gesamentlike Teologiese Studenteblad."”

Hiermee het ons die leser 'n denkbeeld gegee van wat die T.S.V. is en waarna dit strewe. Vecl meer kan nog gesê wořd, ons volstaan egter met bostaande algemene oorsig. Ons bede is dat T.S.V. saam met ons Skool van krag tot krag sal voortgaan. Die groei en bloei van die Skool in die afgelope 75 jaar getuig van die kragtige leiding Gods; dankbaarheid vervul ons harte wat alleen tot uiting kan kom deur in die toekoms, soos in die verlede, alles te benader ooreenkomstig ons leuse: „U Lig en U Waarheid."

Potchefstroom.

G. P. L. VAN DER LINDE. 